\title{
Crowdsourcing \& Marketing: A Relationship in the Making
}

\author{
Prof. Tao Meng ${ }^{1 *}$, Prashant Kumar ${ }^{1} \&$ Bhupender Kumar Som ${ }^{2}$ \\ ${ }^{1}$ Dongbei University of Finance \& Economics, Dalian, China \\ 2 JIMS, Sec-5, Rohini, New Delhi, India \\ *Prof. Tao Meng, E-mail: mengtao@dufe.edu.cn
}

Received: August 25, 2016 Accepted: September 2, 2016 Online Published: September 13, 2016

doi:10.22158/jbtp.v4n2p207～URL: http://dx.doi.org/10.22158/jbtp.v4n2p207

\begin{abstract}
Crowdsourcing seems to have come of age since Jeff Howe christened it in 2006 and the writing on the wall is clear. As more and more companies are trying to jump on the crowdsourcing bandwagon, crowdsourcing as a marketing strategy is cementing its place in the fiercely competitive business environment and it's leading the crowd of strategies which have come to the fore in the recent years. The business corridors are buzzing with this ever evolving phenomenon, which no more seems like another buzz word around. As this phenomenon is gaining currency across boundaries, the academic research around this topic has also gained lot of attention. As a result this paper will draw attention toward the marketer's perspective about crowdsourcing, as they are the one who are the harbinger of the future growth of crowdsourcing. This paper will highlight the level of awareness of crowdsourcing among the marketing managers, their perspective about its use and impact on various marketing strategies. In addition to this, their perspective on digital divide is considered to be discussed, as digital divide could play a spoilsport in the relationship between crowdsourcing and marketing. Most often it is said that if you want to do something different then don't follow the crowd, first time it seems it is good to follow the crowd.
\end{abstract}

\section{Keywords}

crowdsourcing, marketing strategy, digital divide

\section{Introduction}

In this era of highly challenging and fluid business environment, strategy making is a cumbersome task. Every firm is looking forward to maximize the impact of marketing strategies, as designing and implementing a marketing strategy is a costly affair these days. Information \& Communication Technologies make this environment more challenging as it requires you to respond instantly and engage the customer $24 \times 7$. Business world has witnessed and still witnessing a sea change in the way business is conducted these days. ICT is providing a platform for new business models, which were never thought of in the absence of these technologies and out of these technologies which have immensely affected the way we do our business is the internet. The world connected through this internet has unleashed a plethora of opportunities and challenges in the business world and the status-quo is being challenged time and time again. The business world is going through a paradigm shift from top to down approach to down to top approach in the context of managing the consumers. No wonder with this paradigm shift happening around the world, in 2006 the TIME magazine felt indebted, inspired and motivated to name "You" as the person of the year, recognizing "the small contribution of millions of people” (Grossmann, 2006) to the Web 2.0. On each single day the world of internet is inundated with a huge online content and data for which an army of workforce is required to 
extract the required information and every now and then the people are seen collaborating with each other on many issues concerning various spheres of life and business. These interconnected people across the globe are not only contributing to the development of the online community but also improving the experience of Web and proving to be the catalyst for a revolutionary change across the business world. Hence, the corporate world is embracing the idea of collaborating with customers through various social media and internet platforms.

Witnessing such a paradigm shift and seeing more and more companies collaborating with end consumers in the business world Jeff Howe in 2006 coined the term "crowdsourcing" which he described as a process of outsourcing a specific task to a large heterogeneous crowd through an open call. Howe in his book "Crowdsourcing". How the power of crowd is driving the future of business discusses how different categories of business are using the crowdsourcing for their business related activities. His case studies include wide range of industries like Wikipedia sourcing information, Linux sourcing software codes, Thread less a T-shirt manufacturing company sourcing its design, is tock photo a web company sourcing photographs, Procter \& Gamble sourcing ideas from the crowd (Howe, 2008). Don Tapscott and Anthony D. Williams in their book Wikinomics. How Mass Collaboration Changes Everything talks about Ideagoras like Inno Centive which helps companies find solution for their unsolved R\&D problems, he further states that companies need to look beyond their own individual $\mathrm{R} \& \mathrm{D}$ departments and start treating the world as the source of solutions to their problems (Tapscott \& Williams, 2006).

With such a watershed moment in the business environment, no business entity and country can remain immune to changes happening all around the world. In a country which is the largest democracy in the world, it becomes a matter of great curiosity for a researcher to explore the democratization of organizations through crowdsourcing, which until now has been a one way process of manufacturing and delivering to the customers. This paper will explore the awareness of crowdsourcing in the Indian business environment and the marketer's perspective about the impact of crowdsourcing on different marketing strategies. In addition to this, their perspective about digital divide and its impact on crowdsourcing will also be discussed.

\subsection{Crowdsourcing and Marketing}

Who says relationships are made in heaven, these days they are made on internet. As a concept crowdsourcing seems to precede the concept of marketing in the business world and the society at large, but age doesn't seem to matter in this relationship. As it is being said that age is just a number, crowdsourcing and marketing have found something in each other to admire about and get along with each other. The internet is playing the cupid and taking their relationship to the next level. Ample stories are floating around about the success of their relationship and people all across the business world are using this relationship to their benefits.

As mentioned above in introduction part Jeff Howe in his book discuss about wide range of industries like Wikipedia sourcing information, Linux sourcing software codes, Thread less a T-shirt manufacturing company sourcing its design, IStockphoto a web company sourcing photographs, Procter \& Gamble sourcing ideas from the crowd, we can add Facebook and Youtube also to this famous list. Don Tapscott and Anthony D. Williams in their book also talks about Ideagoras like InnoCentive which helps companies find solution for their unsolved R\&D problems. Then there are other big players like Coca-Cola, IBM, Google, Microsoft, GE, McDonald's, Nestle, Samsung, Nokia who all have used crowdsourcing for their various needs. One of the most popular campaign around the world has been the Lay's "Do Us A Flavor" contest in numerous countries getting millions of ideas for 
chips flavors. Till 2014, 85\% of the well-known global brands have put crowdsourcing into practice (Roth, 2015) and crowdsourcing as a professional service has surpassed the figure of 2.5 billion and is expected to reach double the present figure in the next five years (Shingles \& Trichel, 2014).

As far as India is concerned the most earliest example of crowdsourcing can be cited back to the year 1929 when a challenge was thrown open by Gandhiji in 1929 to design the improved spinning wheel with a price tag of INR 1 Lakh (which is worth INR 10 crore now) (Gupta, 2012). One of the biggest crowdsourcing campaigns was a public design contest in 2009 hosted by the Indian Government's finance ministry to create a symbol for the Indian rupee. Thousands of people sent in entries before the government zeroed in on the final symbol based on the Devanagari script using the letter Ra. The corporate world has their own share in Kurkure Diwali Box design contest, Micromax logo redesign etc. The latest being from the stable of one of the biggest business houses of India "Tata Motors", after dropping the name "Zica" for their new car as it resembled the virus Zika, they launched "Fantastico Name Hunt" in Feb 2016 to get a new name. They got 37,000 entries and selected "Tiago" from the final three through social media poll. As crowdsourcing is a process of outsourcing a task normally performed by the company to the general crowd, crowdsourcing campaigns can be used to outsource a marketing activity which is in normal circumstances performed internally. Crowdsourcing can create value for most of the marketing-related activities which prominently includes product development, advertising \& promotion and marketing research (Gatautis \& Vitauskaite, 2014). Like improvement in existing product or new product development can be done, soliciting ideas from crowd through crowdsourcing. Crowdsourcing can also be a good substitute for traditional advertisement agencies, for creating ideas for new commercial and also produce it (Pétavy et al., n.d.). It has great future possibilities of utilization for marketing and market research (Djelassi \& Decoopman, 2013; Whitla, 2009). As voting is also one of the domain of crowdsourcing, it has the ability to substitute the traditional studies to examine whether a product satisfy the need or want of the market and even estimate the demand through voting based platform, as happens in a US based company called Threadless. Likewise there are possibilities of doing many other kind of research through crowdsourcing.

The other most talked about benefits or approach of crowdsourcing is customer engagement. The “consumer engagement concept centers on specific interactive consumer experiences” (Brodie et al., 2013), which helps the company's to have a healthy relationship with their consumers. Web 2.0 and the disruptive innovation in technologies increased the possibilities for companies to interact with customers manifold. The most important benefit of engaging customers is increased brand loyalty from the customers (Füller et al., 2013). There is a big possibility that most engaged customers might become brand advocates, which in turn can create a multiple effect in the form of eWOM. The satisfied participants of a crowdsourcing campaign might share their brand experiences with others online, thus creating positive eWOM (Marsden, 2009). This eWOM can be considered as a free promotion and the best scenario out of it would be the viral diffusion of information and the increased popularity of the campaign itself (Füller et al., 2013). Consequently, the crowdsourcing campaign might create the much talked "buzz" (Djelassi \& Decoopman, 2013; Prahlad \& Ramaswamy, 2000), and this buzz can result in reporting of crowdsourcing campaign by different media outlets. At the same time it is important to be careful about a situation that if the campaign is not embraced positively by customers then eWOM can instantly turn into negative publicity and the company image could be tarnished in the process.

In their study Vukovic also talk about crowdsourcing use in enterprises marketing, design, innovations, development \& testing, support and crowd analytics possibilities for predictions about the discussed 
issue (Vukovis, 2009). Marsden in his study mentioned that companies use crowdsourcing campaigns as a promotional and strategic marketing tool to engage and increase awareness among the customers (Marsden, 2009). Beard talk about crowdsourcing in content marketing activities (Beard, 2013). Getting inputs from user for product development as a phenomenon is not new (von Hippel, 1998; 2006) it is just that internet has made it easy and crowdsourcing has given the much needed impetus to it. The examples cited above and the finding from the literature review do suggest that crowdsourcing and marketing are into a relationship and the relationship has got the biggest brands of the world on their side as brand ambassador for promoting their relationship.

\subsection{Digital Divide}

As per the OECD's definition digital divide is a gap between individuals, household, businesses and geographical areas at different socio-economic levels with regard both to their opportunities to access ICTs and to their use of the Internet for a wide variety of activities. As evident from the literature that crowdsourcing as a concept gained currency in the era of internet and internet as a medium of communication has issues like accessibility, affordability and user skills as a bottleneck in its growth. It is these issues which divide the society digitally. Korea Agency for Digital Opportunity \& Promotion in their report "How to measure digital divide" talk about digital divide in terms of access, ability and usage. The Economist Intelligence Unit in their report commissioned by Huawei also talk about accessibility, affordability and user skills as the factors which contribute to digital divide. Karine Barzilai Nahon in their paper also discuss about accessibility, affordability and user skills as the various factors contributing to digital divide at different levels of society (Nahon, 2006). In this paper marketing managers' perspective of digital divide is measured in the context of accessibility, affordability and user skills regarding ICT. As in-depth study of digital divide is not the focus of this paper, we have just used accessibility, affordability and user skills as three parameters in our questionnaire to get the perspective of marketers regarding digital divide.

\section{Research Methodology}

The research methodology is designed for two phases of this paper, exploratory research and descriptive research. Hence an exploratory study is performed by following methods:

1) Open ended questionnaire amongst respondents;

2) Literature survey;

3) Brain storming.

After completion of exploratory study, a close ended questionnaire is developed for marketers. The reliability and validity of questionnaire is checked by using Chorback Alpha which was found to be .7 quite above the desired mark. After checking reliability and validity of questionnaire, required corrections are made in questionnaire. Likert's scale is used to get the responses from the respondents. Once the questionnaire is finalized, a soft form by using Google forms facility is generated and floated amongst marketers for responses. A snowball sampling technique is used to reach the desired sample size.

The responses are then coded to spreadsheets and statistical tools like correlation \& regression and ANNOVA are applied for understanding of results. The data analysis is presented in two phases: fundamental analysis and advance analysis. In fundamental data analysis section the sample outcomes are presented through charts and tables and required percentage is also calculated. In advance data analysis inferential statistics is obtained. 


\section{Data Analysis}

As mentioned above the data analysis is divided in to two parts. In subsection 5.1 the sample results are presented through suitable charts. The understanding of sample outcome can be cited from this section. In subsection 3.2 generalization of sample outcomes and inferential statistics is performed.

\subsection{Sample Results}

In this section all questions of descriptive questionnaire are explored and outcomes are presented. In a country like India it was essential to understand the level of awareness of crowdsourcing in India. Hence at the first step respondents are asked about awareness of crowdsourcing. The following diagram shows the level of awareness.

\section{Awareness of Crowdsourcing}

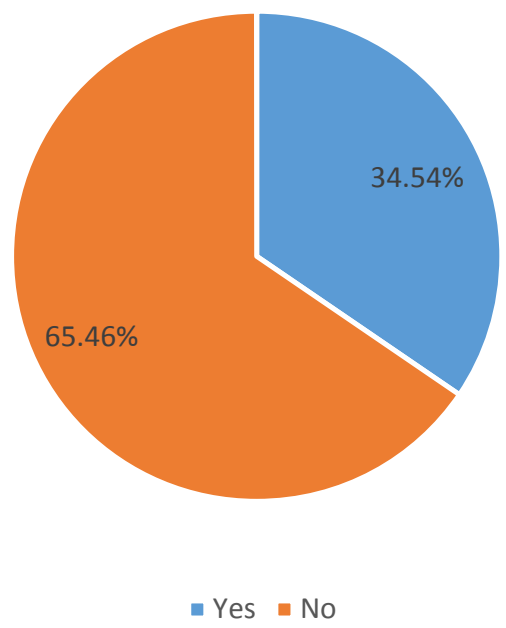

Figure 1. Level of Awareness

The Figure shows that a large number of people are not aware about crowdsourcing. Sample depicts that many people in the corporate are not very much familiar with crowdsourcing. In questionnaire a brief of crowdsourcing is introduced right after knowing the awareness of respondent about the term. After giving a brief about crowdsourcing, the question is asked about the best description of crowdsourcing. Following Figure depicts the outcome. 


\section{Description of Crowdsourcing}

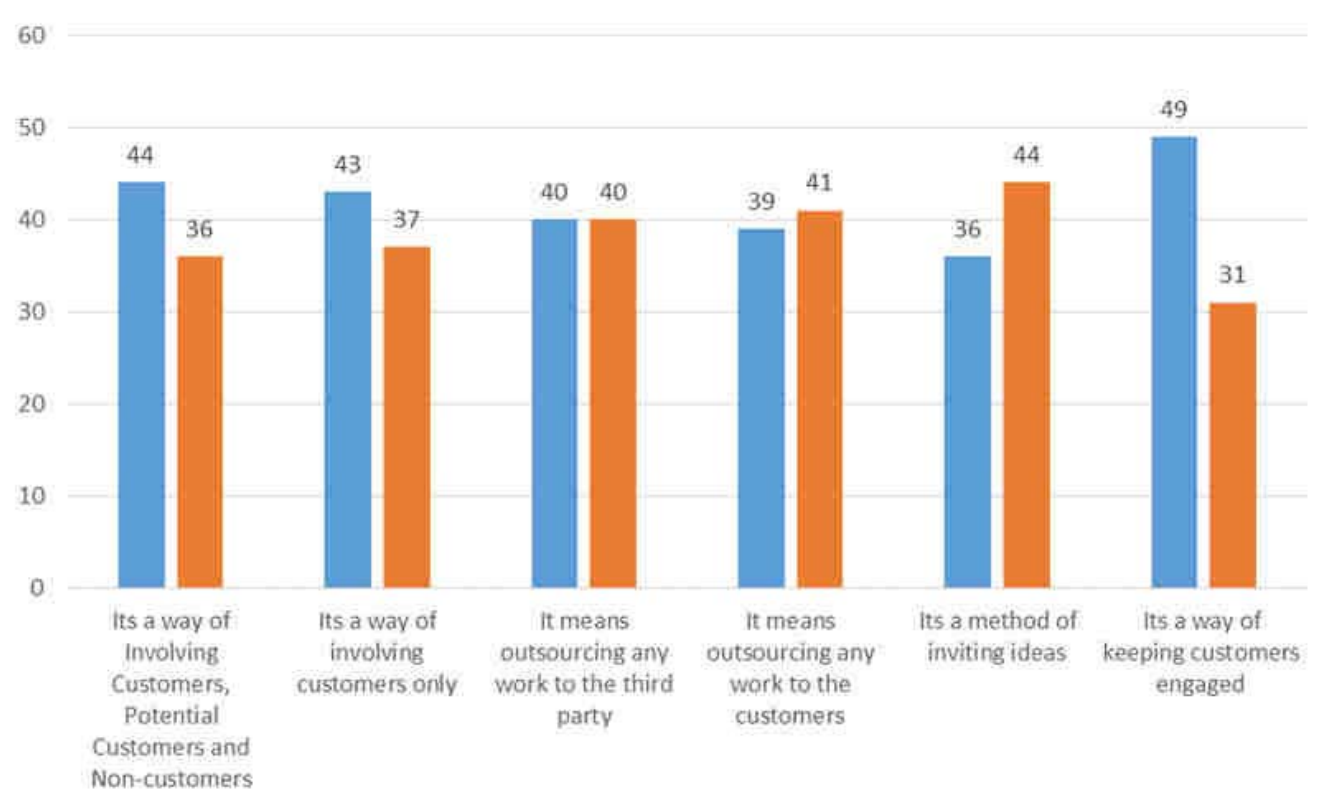

Figure 2. Crowdsourcing Defined

Figure 2 shows that most of the marketing managers thinks that it's a way of keeping the customers engaged. This goes in sync with the idea of crowdsourcing that explains customers' involvement. Since respondents are now familiar with the term crowdsourcing. Understanding the impact of crowdsourcing was most logical question to ask next. Hence the respondents are asked about the impact of crowdsourcing on certain marketing functions. These function are listed in accordance to the exploratory study conducted in phase 1through literature review, open ended questionnaire responses and rigorous brain storming. It was asked that how much crowdsourcing impacts the following marketing functions as per marketers' knowledge.

Brand Name selection

Product packaging

Introduction of variety (flavour/colour/type/form )

Advertising

Product development—how product should develop over years

Customer engagement

Customer feedback

Concept testing

Advocating the brand

Creative designing (flyers/banners, etc.)

Community development (collective actions that address issues of public concern)

Generate funds (for profit or not profit organizations)

- $\quad$ Content marketing 
Table 1. Effectiveness of Crowdsourcing on Marketing Functions

\begin{tabular}{|c|c|c|c|c|c|}
\hline & $\begin{array}{l}\text { Lease } \\
\text { Effective } \\
\text { (1) }\end{array}$ & 2 & 3 & 4 & $\begin{array}{l}\text { Most } \\
\text { Effective } \\
\text { (5) }\end{array}$ \\
\hline Brand Name selection & $39.51 \%$ & $18.52 \%$ & $16.05 \%$ & $8.64 \%$ & $17.28 \%$ \\
\hline Product packaging & $12.35 \%$ & $22.22 \%$ & $14.81 \%$ & $13.58 \%$ & $37.04 \%$ \\
\hline Introduction of variety & $16.05 \%$ & $14.81 \%$ & $13.58 \%$ & $16.05 \%$ & $39.51 \%$ \\
\hline Advertising & $29.63 \%$ & $13.58 \%$ & $29.63 \%$ & $17.28 \%$ & $9.88 \%$ \\
\hline Product development & $16.05 \%$ & $16.05 \%$ & $17.28 \%$ & $11.11 \%$ & $39.51 \%$ \\
\hline Customer engagement & $23.46 \%$ & $13.58 \%$ & $12.35 \%$ & $17.28 \%$ & $33.33 \%$ \\
\hline Customer feedback & $18.52 \%$ & $13.58 \%$ & $13.58 \%$ & $7.41 \%$ & $46.91 \%$ \\
\hline Concept testing & $34.57 \%$ & $8.64 \%$ & $14.81 \%$ & $20.99 \%$ & $20.99 \%$ \\
\hline Advocating the brand & $44.44 \%$ & $12.35 \%$ & $4.94 \%$ & $22.22 \%$ & $16.05 \%$ \\
\hline designing & & & & & \\
\hline (flyers/banners, etc.) & $9.88 \%$ & $22.22 \%$ & $20.99 \%$ & $17.28 \%$ & $29.63 \%$ \\
\hline Community development & $34.57 \%$ & $12.35 \%$ & $11.11 \%$ & $20.99 \%$ & $20.99 \%$ \\
\hline Generate funds & $32.10 \%$ & $19.75 \%$ & $17.28 \%$ & $13.58 \%$ & $17.28 \%$ \\
\hline Content marketing & $29.63 \%$ & $17.28 \%$ & $17.28 \%$ & $17.28 \%$ & $18.52 \%$ \\
\hline
\end{tabular}

From Table 1 it can be easily understood that a high number of people think crowdsourcing is most effective in taking customer feedback, it is also highly effective in adding variety to the product and product development. Advocating the brand is least affected by crowdsourcing. Next the respondents are asked whether their organization is practicing crowdsourcing or not. The responses are clubbed as under.

\section{Organizations Practicing Crowdsourcing}

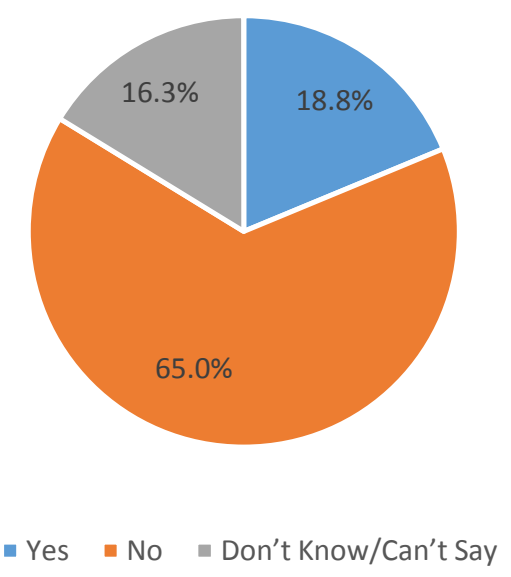

Figure 3. Organizations Practicing Crowdsourcing

Form Figure 3, it can be seen that level of organizations not practicing crowdsourcing is nearly equal to the percentage of unawareness of people about crowdsourcing. 
It was essential to know how people compare traditional marketing with crowdsourcing. Hence effectiveness of crowdsourcing with respect to traditional marketing strategies is measured for various parameters involved in business.

Table 2. Effectiveness of Crowdsourcing

\begin{tabular}{lll}
\hline & Crowdsourcing & \\
& Strategies & Other Marketing Strategies \\
\hline Cost effective & $33.75 \%$ & $66.25 \%$ \\
Time effective & $35.00 \%$ & $65.00 \%$ \\
Manpower effective & $45.00 \%$ & $55.00 \%$ \\
More impactful & $58.75 \%$ & $41.25 \%$ \\
Ease of implementation & $42.50 \%$ & $57.50 \%$ \\
More involvement/higher reach & $67.50 \%$ & $32.50 \%$ \\
Ease of measurement & $63.75 \%$ & $36.25 \%$ \\
Life of campaign & $47.50 \%$ & $52.50 \%$ \\
Creativity/Freshness & $72.50 \%$ & $27.50 \%$ \\
\hline
\end{tabular}

Table 2 shows that on parameters of creativity, involvement, ease of measurement and impact crowdsourcing wins the race. While it is observed that marketers do not find crowdsourcing cost and time effective. This finding goes against the general perception that crowdsourcing is cost effective and time effective but as N. Beard (2013) says crowdsourcing can be time consuming depending on the quantity of responses from the crowd and managing huge response can also have a significant cost of management. As this study is about what marketers think, not about why they think, this perception can be further explored.

Moving forward, it has to be checked what marketers think about digital divide. Hence a question about the level of digital divide is raised.

\section{Level of Digital Divide In India}

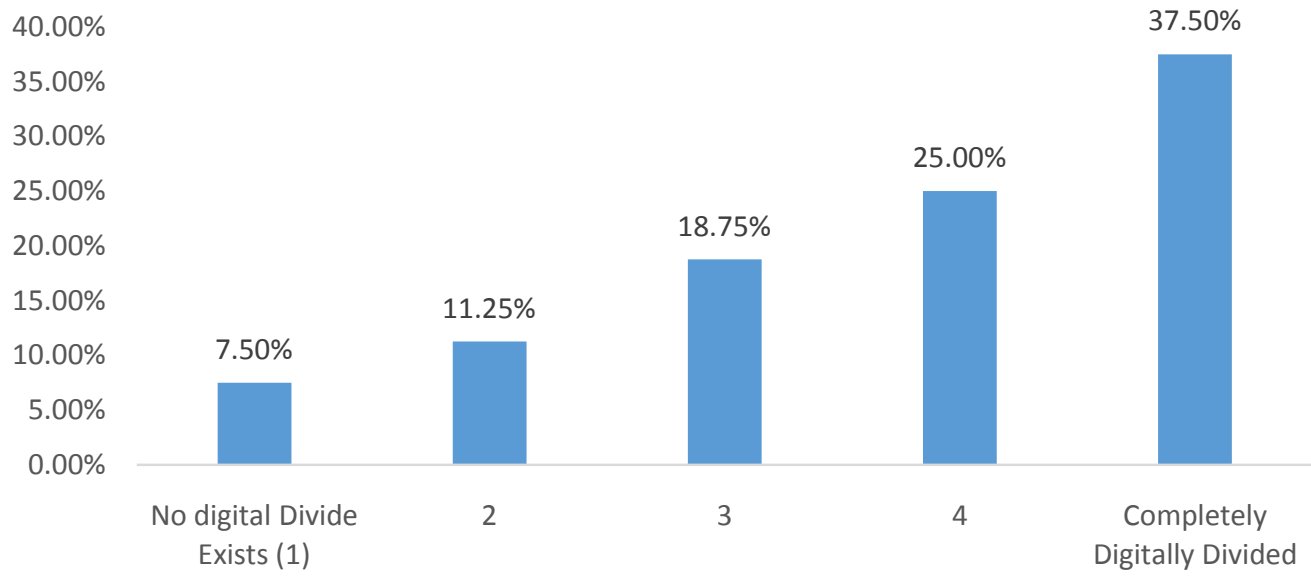

(5)

Figure 4. Level of Digital Divide 
It is observed that people strongly believe that level of digital divide is high in India. The average score for above question is 3.73 which clearly indicated a high level of digital divide. Further, digital divide is measured on 7 different parameters namely:

1) Can afford have access but do not have skill;

2) Can afford do not have access but have skill;

3) Can afford do not have access and do not have skills;

4) Cannot afford have access also have skill;

5) Cannot afford have access but do not have skill;

6) Cannot afford do not have access but have skill;

7) Cannot afford do not have access and do not have skills;

Responses are recorded at a 5 point Likert scale. Following table compiles the responses. A highest score of 5 is assigned to strong agreement and least score of 1 is assigned to strong disagreement.

Table 3. Digital Divide Parameters and Level of Agreement

\begin{tabular}{lccccc}
\hline & $\begin{array}{c}\text { Strongly } \\
\text { Agree }\end{array}$ & $\begin{array}{c}\text { Somewhat } \\
\text { Agree }\end{array}$ & Agree & $\begin{array}{c}\text { Somewhat } \\
\text { Disagree }\end{array}$ & $\begin{array}{c}\text { Strongly } \\
\text { Disagree }\end{array}$ \\
\hline $\begin{array}{l}\text { Can afford have access but do not } \\
\text { have skill }\end{array}$ & $17.50 \%$ & $12.50 \%$ & $21.25 \%$ & $17.50 \%$ & $31.25 \%$ \\
$\begin{array}{l}\text { Can afford do not have access but } \\
\text { have skill }\end{array}$ & $16.25 \%$ & $18.75 \%$ & $15.00 \%$ & $18.75 \%$ & $31.25 \%$ \\
$\begin{array}{l}\text { Can afford do not have access and } \\
\text { do not have skills }\end{array}$ & $15.00 \%$ & $13.75 \%$ & $22.50 \%$ & $27.50 \%$ & $21.25 \%$ \\
$\begin{array}{l}\text { Cannot afford have access also have } \\
\text { skill }\end{array}$ & $38.75 \%$ & $13.75 \%$ & $15.00 \%$ & $16.25 \%$ & $16.25 \%$ \\
$\begin{array}{l}\text { Cannot afford have access but do } \\
\text { not have skill }\end{array}$ & $26.25 \%$ & $16.25 \%$ & $16.25 \%$ & $20.00 \%$ & $21.25 \%$ \\
$\begin{array}{l}\text { Cannot afford do not have access } \\
\text { but have skill }\end{array}$ & $15.00 \%$ & $23.75 \%$ & $23.75 \%$ & $13.75 \%$ & $23.75 \%$ \\
$\begin{array}{l}\text { Cannot afford do not have access } \\
\text { and do not have skills }\end{array}$ & $17.50 \%$ & $21.25 \%$ & $21.25 \%$ & $18.75 \%$ & $21.25 \%$ \\
\hline
\end{tabular}

Table 4. Average Score of Parameters of Digital Divide

\begin{tabular}{ll}
\hline Digital Divide Parameters & Average Score \\
\hline Can afford have access but do not have skill & 2.68 \\
Can afford do not have access but have skill & 2.70 \\
Can afford do not have access and do not have skills & 2.74 \\
Cannot afford have access also have skill & 3.43 \\
Cannot afford have access but do not have skill & 3.06 \\
Cannot afford do not have access but have skill & 2.93 \\
Cannot afford do not have access and do not have skills & 2.95 \\
\hline
\end{tabular}




\section{Digital divide parameters Vs overall opinion}

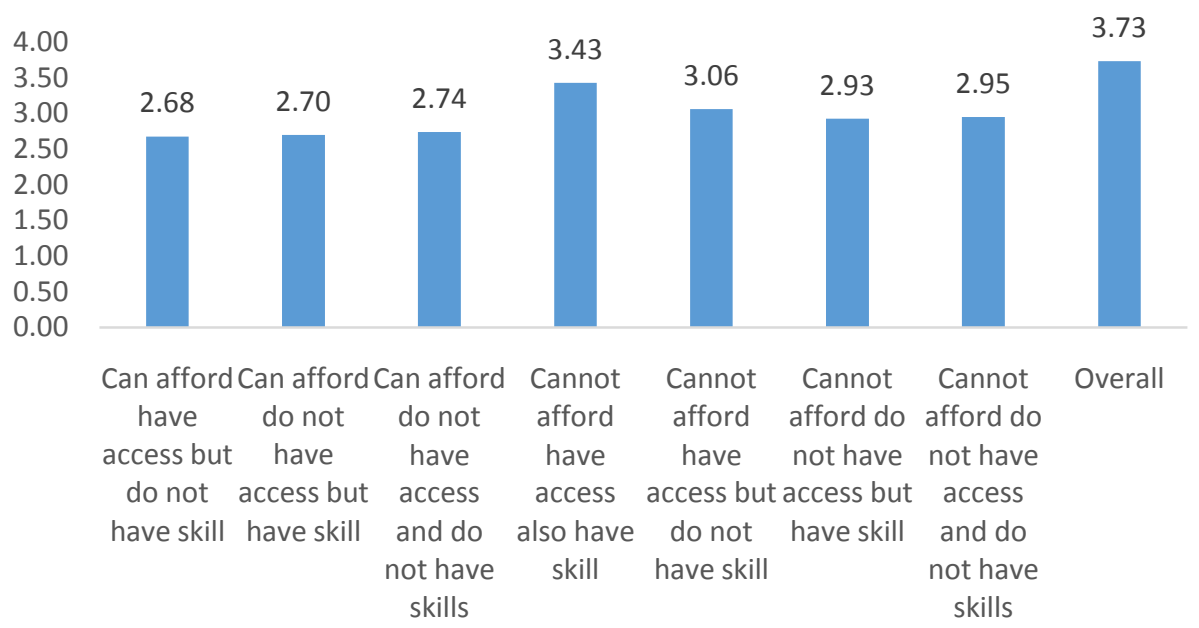

Figure 5. Digital Divide Opinion

\subsection{Hypothesis Formulation and Inferences}

By going through a rigorous literature review, observation and brain storming following hypotheses were formed at a $95 \%$ level of confidence.

$H_{00}$ : Crowdsourcing has same effect on all marketing functions;

$H_{11}: H_{00}$ is not true;

The second hypothesis is formulated for testing the impact of digital divide on crowdsourcing. Logically a high digital divided shall lead to a less impact of crowdsourcing as a high digital divide leads to lesser use of internet facilities. We took $p_{1}$ as proportion of sample of marketers who said that yes digital divide impacts crowdsourcing phenomenally while $p_{2}$ represents the proportion of people which say digital divide doesn't affect crowdsourcing highly. Following hypothesis is formulated for generalization of results.

$H_{11}: p_{1} \geq p_{2}$

$H_{12}: H_{11}$ is not true.

Above mentioned hypotheses are tested with appropriate statistical tools. $H_{00}$ is tested with analysis of variance (ANOVA, Table-5). While, H01is tested by using z-test for comparison of proportions. Effect of different parameters of digital divide will be measured in future work by using multiple regression on overall digital divide.

Table 5. Single Factor ANOVA for $\boldsymbol{H}_{\mathbf{0 0}}$

\begin{tabular}{lllllll}
\hline ANOVA & \multicolumn{7}{l}{} & & & & \\
\hline Source of Variation & SS & $d f$ & MS & $F$ & P-value & F crit \\
Between Groups & 160.3837 & 12 & 13.36530548 & 5.812682416 & $8.12 \mathrm{E}-10$ & 1.761474 \\
Within Groups & 2391.309 & 1040 & 2.299335233 & & & \\
\hline Total & & & & & & \\
\hline
\end{tabular}

From Table 5 it is observed that, null hypothesis that Crowdsourcing has same effect on all marketing functions and $H_{00}$ is rejected. Since f-value is higher than $\mathrm{f}$-critical. 
For testing of $H_{01}$ a two sample proportion z-test for that the test statistics is given by:

$$
z=\frac{\widehat{p_{1}}-\widehat{p_{2}}}{\sqrt{\frac{p_{1} q_{1}}{n_{1}}+\frac{p_{2} q_{2}}{n_{2}}}}=\frac{\widehat{p_{1}}-\widehat{p_{2}}}{\sqrt{\hat{p} \hat{q}\left(\frac{1}{n_{1}}+\frac{1}{n_{2}}\right)}}=2.96
$$

At $\alpha=0.5$, calculated value of $\mathrm{z}$ is more than $\mathrm{z}$ critical in right tail test hence we reject null hypothesis We observe that high proportion of the marketers think that digital divide doesn't have an impact on crowdsourcing. This could be due to different innovative ideas that are used by marketers to reduce the impact of digital divide on crowdsourcing. Marketers may opt for alternative ways of crowdsourcing rather than using information and communication technology.

\section{Conclusion}

The results of this paper are extremely useful for the firms inculcating crowdsourcing for marketing activities. The paper tells us that there is a low awareness of crowdsourcing in India even among professionals. Hence a larger level of awareness is required before it can be practiced and marketers can get benefited from it. The level of awareness can be improved by including crowdsourcing in syllabus of marketing subject at university level.

In future we would be exploring the knowledge and awareness amongst academicians in India. Also we will be measuring the attitude of academicians towards crowdsourcing.

The paper also gives an insight that marketers think that crowdsourcing does not have equal impact on all functions of marketing. The effect varies from function to function. That is on some marketing functions the impact is more and in some it is less. The mean scores of impact give a clear understanding of impact measurement.

It can also be observed that digital divide doesn't have a phenomenal impact on crowdsourcing and the marketers find another ways to generate responses from crowd for, e.g., radio call programs, tele calling, post-mail or else.

As crowdsourcing is a very new concept in marketing and leaves a high scope of exploration. In this work we have given a new dimension to connect digital divide and crowdsourcing. The study will further be extended to another stakeholders, i.e., customers and to academicians.

\section{References}

Beard, N. (2013, October 21). Content Marketing: How Crowdsourcing Can Inspire Great B2B Content Ideas [Web log post]. Retrieved from http://www.toprankblog.com/2013/09/crowdsourcing-as-content-inspiration/

Brodie, R. J., Ilic, A., Juric, B., \& Hollebeek, L. (2013). Consumer Engagement in a Virtual Brand Community: An Exploratory Analysis. Journal of Business Research, 66(1), 105-114. http://dx.doi.org/10.1016/j.jbusres.2011.07.029

Djelassi, S., \& Decoopman, I. (2013). Customers' Participation in Product Development through Crowdsourcing: Issues and Implications. Industrial Marketing Management, 42(5), 683-692. http://dx.doi.org/10.1016/j.indmarman.2013.05.006

Füller, J., Bilgram, V., Koch, G., \& Rapp, M. (2013). The Potential of Crowdsourcing for Co-Marketing: How Consumers May Be Turned into Brand Ambassadors. Transfer Werbeforschung \& Praxis, 59(4), 42-48. 
Gatautis, R., \& Vitauskaite, E. (2014). Crowdsourcing Application in Marketing Activities. $\begin{array}{llll}\text { Procedia-Social and } \quad \text { Behavioral } & \text { Sciences, } & 110, & 1243-1250 .\end{array}$ http://dx.doi.org/10.1016/j.sbspro.2013.12.971

Grossmann, L. (2006). You-Yes, You-Are TIME's Person of the Year, TIME Magazine Online, 25th December. Retrieved

from http://www.content.time.com/time/magazine/article/0,9171,1570810,00

Gupta, A. (2012). Innovation, Investment, Enterprise: Generating Sustainable Livelihood at Grassroots Through Honey Bee Philosophy.

Howe, J. (2006). The Rise of Crowdsourcing, Wired Magazine Online. Retrieved from http://www.archive.wired.com/wired/archive/14.06/crowds.html

Howe, J. (2008). Crowdsourcing: How the Power of the Crowd is Driving the Future of Business. New York: The Crown Publishing Group.

Marsden, P. (2009). Crowdsourcing: Your Recession-Proof Marketing Strategy? Contagious Magazine, $18,24-28$.

Nahon, K. B. (2006). Gaps and Bits: Conceptualizing Measurements for Digital Divide/s. The Information Society, 22, 269-278. http://dx.doi.org/10.1080/01972240600903953

Pétavy, F., Céré, J., Tan, C., \& Roth, Y. (n.d.). Online Co-Creation to Accelerate Marketing and Innovation (white paper), eYeka. Retrieved from https://www.de.eyeka.com/resources/whitepapers

Prahalad, C. K., \& Ramaswamy, V. (2000). Co-Opting Customer Competence. Harvard Business Review, 78(1), 79-90.

Roth, Y. (2015). The State of Crowdsourcing in 2015.

Shingles, M., \& Trichel, J. (2014). Industrialized Crowdsourcing Tech Trends 2014. Deloitte $\begin{array}{llll}\text { University } \quad \text { Press } & \text { online. } & \text { Retrieved }\end{array}$ http://www.dupress.com/articles/2014-tech-trends-crowdsourcing/?coll=6210

Tapscott, D., \& Williams, A. D. (2006). Wikinomics. How Mass Collobaration Changes Everything. USA: Penguin Group.

Von Hippel, E. (1998). The sources of innovation. London and New York: Oxford University Press.

Von Hippel, E. (2006). Democratising innovation. Cambridge, MA: MIT Press.

Vukovic, M. (2009). Crowdsourcing for Enterprises. 2009 World Conference on Service. http://dx.doi.org/10.1109/services-i.2009.56

Whitla, P. (2009). Crowdsourcing and Its Application in Marketing Activities. Contemporary Management Research, 5(1), 15-28. http://dx.doi.org/10.7903/cmr.1145 